\title{
PERFORMANCE ANALYSIS OF A SELF- PROTECTION SYSTEM FOR VEHICLES IN CASE OF WUI FIRE ENTRAPMENT
}

\author{
Elsa Pastor ${ }^{1, *}$, Alba Àgueda ${ }^{1}$, Juan Sebastià ${ }^{2}$, Christian Mata ${ }^{1}$, Mario Miguel Valero ${ }^{1}$, Eulàlia Planas ${ }^{1}$ \\ ${ }^{1}$ Centre for Technological Risk Studies (CERTEC), Department of Chemical Engineering, Universitat \\ Politècnica de Catalunya $\cdot$ BarcelonaTech, Catalonia \\ ${ }^{2}$ Wildfire Security S.L., Spain \\ * Corresponding author: elsa.pastor@upc.edu
}

\begin{abstract}
We present the experimental performance analysis of a fire protection fabric for cars designed to protect people's life in case of fire entrapment. Two experimental burns were executed to simulate heat and smoke exposure conditions in case of vehicle entrapment in a rural road. For the first experimental burn, a 2-m high fuel bed of pine slash was arranged in a $13 \mathrm{~m} \times 6 \mathrm{~m}$ area. Fire was ignited at one end of the fuel bed and spread wind driven ( $3 \mathrm{~m} / \mathrm{s}$ midflame wind speed). $2.8 \mathrm{~m}$ away from the other fuel bed end, a car covered with the fabric was placed parallel to the fire. Data analysis provided values of fire behaviour and flame characteristics, being typical of wildfires of moderate intensity $(1800 \mathrm{~kW} / \mathrm{m})$.. Maximum air temperatures inside the vehicle ranged around $41-42.5^{\circ} \mathrm{C}$, providing evidence of the fabric's good performance. To evaluate the degree of protection against smoke, air change rates were estimated with and without the fabric covering the car. Also, an experimental burn similar to the previous one was executed to monitor $\mathrm{CO}_{2}$ and $\mathrm{CO}$ concentrations inside the car. Tenable conditions for these gases were maintained during the whole test according to reviewed exposure criteria.
\end{abstract}

\section{INTRODUCTION}

Wildfires affecting communities represent a rising problem throughout the world. As the climate warms, hot and dry seasons are lengthening and wildfires are behaving more often as real fire storms with huge intensities and large destructive potential. In addition, human pressure at the wildland-urban interface (WUI) is continuously growing with an increase of ignitions, structures and population density in areas with high forest fire risk. WUI fires pose major management challenges in terms of civil protection and fire mitigation. These fires often exceed firefighter's capacities, who have to respond simultaneously to wildfire suppression, community evacuation and structures protection, hence becoming self-protection a growing need.

Recent WUI fire events have involved fatal consequences for population. Fire incident analysis has revealed that many of the casualties correspond to people caught on the road, either on foot or in vehicles, trying to escape from the fire. For instance, in 2017, Portugal experienced the deadliest WUI fires in its history, with more than 110 deaths. Particularly, 58 of them died in or near their cars when the fire overtook several rural roads. Wildfire in Attica (July 2018, Greece) also killed 99 people, a fair amount of them burnt in houses and cars. Thousands of vehicles were trapped when fleeing from the fire heading to the coastline.

Sheltering inside a civilian vehicle has proved to be a high risk strategy in case of wildfire entrapment. Survival is by no means guaranteed, especially in moderate to high-intensity wildfires ${ }^{1}$. However, vehicles do offer a certain degree of fire protection, which can be reinforced by ad-hoc fire resistant technology. 
Literature on firefighter shelters effectiveness exists ${ }^{1,2}$ and a comprehensive review about fire blankets used to protect building structures has been recently published ${ }^{3}$. However, there is limited literature available (no peer-reviewed papers, according to the authors' knowledge) about the safety of people becoming entrapped in vehicles. In Table 1 studies conducted to monitor and compare air toxic levels, temperature and radiation conditions inside firefighters' engines and civilian cars are presented. Based on these results and considering recommendations of fire researchers, Australasian Fire Authorities Council provided guidelines for people who do find themselves in cars during bushfires ${ }^{4}$. The following advices are examples of those included in the document: 1 . The car should be parked, ideally, on a noncombustible surface and should be positioned towards the oncoming fire front; 2. Inside the car, windows and doors should be tightly shut, the car vents should be closed, the engine should be turned off, occupants need to get down as low as possible (below the window level), and water should be drunk if possible to avoid dehydration.

As shown in Table 1, Mangan (1998) $)^{5}$ tested firefighting vehicles and fire shelters in open field burns that reached high intensity heat fluxes (up to $150 \mathrm{~kW} / \mathrm{m}^{2}$ ). In this work details about test procedures and methods were very complete, but tenable and survivable cabin conditions were not mentioned. On the contrary, in the work from Brown et al. $(2003)^{6}$ tenability and survivability conditions were comprehensively reviewed for air toxics. For instance, $\mathrm{CO}$ exposure criteria for tenability and survivability were $100 \mathrm{ppm}$ and $1000 \mathrm{ppm}$, respectively. In the work from Knight et al. (2003) ${ }^{7}$ survivable cabin conditions for temperature and radiation exposures were established as limiting values that should only be endured for less than a minute, i.e. $2 \mathrm{~kW} / \mathrm{m}^{2}$ of radiation direct to the person and 200 ${ }^{\circ} \mathrm{C}$ of blast of hot air. Sargeant et al. (2007) ${ }^{8}$ referred to Brown et al. $(2003)^{6}$ for air toxics tenable and survivable conditions, and survivable cabin conditions for temperature and radiation exposures were based on Knight et al. (2003) ${ }^{7}$ work.

Maximum/minimum inside temperatures registered in the works from Sargeant et al. $(2007)^{8}$ and Mangan $(1998)^{5}$ were $312.4{ }^{\circ} \mathrm{C} / 38{ }^{\circ} \mathrm{C}$ and $280{ }^{\circ} \mathrm{C} / 60{ }^{\circ} \mathrm{C}$, respectively. Maximum temperatures were registered in tests where the physical integrity of the vehicle was breached.

Another approach for protecting firefighters in case of fire entrapment was invented in Australia, that is the so-called Burn Over Protection Unit ${ }^{9}$. Folded into a cabinet on top of the water tanks at the rear of a fire pump truck, the hi-tech heat resistant "tent" drops down over three people in a matter of seconds, providing a temporary protective refuge while a fire front passes ${ }^{9}$. This system was devised as an alternative from staying in the cab of the vehicle, where smoke and plastic fumes can accumulate.

In Portugal recent research efforts are being carried out to implement a fabric that can be used to protect firefighters sheltering in the cabins during burnover. According to the main researcher of the FIRE PROTECT project, thanks to this fabric maximum temperatures between $50{ }^{\circ} \mathrm{C}$ and $60^{\circ} \mathrm{C}$ can be reached inside firefighters vehicles. Despite they mention that the fabric would be an option for protecting civilian cars, they consider that it would not be suited for protecting people staying inside their vehicles ${ }^{10}$. In fact, the threshold for pain regarding ambient temperature $\left(46^{\circ} \mathrm{C}\right)$ is lower than the abovementioned temperature range. Moreover, $50{ }^{\circ} \mathrm{C}$ is also considered intolerable with dew-points greater than $25^{\circ} \mathrm{C}^{11}$.

In this paper, we present the experimental performance analysis through a heat exposure and a gas exposure test of a self-protection system that has been designed to protect people's life in case of fire entrapment. Similar to a firefighter fire shelter, the designed system consists of $1 \mathrm{~mm}$ depth 3-layer fabric (aluminium, intumescent material and ceramic foils). It is lightweight $\left(608 \mathrm{~g} / \mathrm{m}^{2}\right)$, fire resistant and can be quickly deployed covering the whole vehicle. In case of fire exposure, this fabric provides additional heat protection to the occupants and to the vehicle itself, and can block exposure to combustion products (e.g. CO and smoke particles). 


\section{MATERIALS AND METHODS}

\section{Heat exposure test \\ Experimental layout}

An experimental burn was designed to simulate real fire exposure conditions in case of vehicle entrapment in a rural road. The vehicle is considered to be at rest because entrapments in stopped vehicles are common since the engines stop in the absence of oxygen. An ex-situ 2-m high fuel bed of fine Pinus halepensis logging slash was arranged in a $13 \mathrm{~m}$ long x $6 \mathrm{~m}$ wide flat area at the Wildfire Security SL outdoor testing facilities (Puçol, Spain). The fuel bed had 3 zones (A, B, C), being two of them continuous (A and B). Between these zones and zone $\mathrm{C}$, there was a $6.1-\mathrm{m}$ wide fuel-cleared space simulating a road, in which a car (Renault Mégane Sedan) was located (Figure 1).

Fuel load and fuel continuity was qualitatively assessed. Fuel in zone A was mainly horizontally oriented whereas fuel in zone $\mathrm{B}$ and $\mathrm{C}$ had vertical orientation. As a reference, the fuel bed could be treated as a logging slash fuel model in zone A and as a high density sapling stand fuel model in zones B and C. However, no specific assignation could be done to any particular standard fuel model (i.e. those from ${ }^{12}$ or ${ }^{13}$ ) since no quantitative fuel sampling was performed to measure fuel parameters.

\section{Data acquisition}

During the burn, different sensors were deployed to characterize environmental variables, fire behaviour parameters and the efficiency of the fire-protection fabric. Regarding environmental variables, ambient temperature, relative humidity and $2.5 \mathrm{~m}$ wind speed and direction were monitored at $30 \mathrm{~m}$ distance from the SE side of the fuel bed (Kestrel 4500 , Kestrelmeters, 1 datum every 30 seconds). Fuel samples ( $<6 \mathrm{~mm}, 0.6 \mathrm{~cm}-2.5 \mathrm{~cm}$ ) were randomly collected 10 minutes before ignition and oven-dried in the laboratory $\left(90^{\circ} \mathrm{C}, 24 \mathrm{~h}\right)$ for moisture content analysis. An airflow parallel to the fuel bed orientation was induced one minute before ignition using a fan located at $5 \mathrm{~m}$ from the southern corner of the fuel bed. Induced wind speed was monitored at $1.5 \mathrm{~m}$ with a portable anemometer (Kestrel 4500, Kestrelmeters) by the time of ignition. Fire behaviour was monitored by infrared (IR) recording systems (Table 2) and video cameras (one of them mounted on a surveillance drone from the València Fire Emergency Agency). The efficiency of the fire protection fabric was deduced by analysing temperature data acquired inside and outside the vehicle and between the fabric and the vehicle, during the fire progression. K-type thermocouples $\left(0.5 \mathrm{~mm}\right.$ and $1 \mathrm{~mm}$ diameter) were used connected to data $\mathrm{HOBO}{ }^{\circledR}$ Onset U12-014 data loggers (1 datum per second). Table 3 shows the thermocouples numbering system and their location, Figure 2 shows the schematic position of the thermocouples and Figure 3 depicts several images of the experimental methodology.

Figure 1. a) 3D sketch of the experimental layout. Doted red line shows the ignition zone (a 6-m ignition line was performed by professional fire-fighters using drip-torches in less than one minute); b) Plan view of equipment location (distances in $\mathrm{m}$ ).

Figure 2. Scheme of thermocouples position. Dashed line refers to the fabric. Triangles refer to thermocouples positioned outside the fabric; crosses refer to thermocouples positioned in-between the fabric and the car; circles refer to thermocouples positioned inside the car. Car image source: ${ }^{14}$.

Figure 3. Experimental design: a) side view of the experimental site; b) top view; c) thermocouples located at the co-pilot seat at head's height (Ti 5 and Ti 6, according to Table 3); d) thermocouple located at the internal side of driver's window (Ti w, according to Table 3)

\section{Gas exposure protection}

During a wildfire the air inside the car may provide temporary protection against the toxic atmosphere 
that is created outdoors. The level of protection provided by the vehicle varies with the rate at which outdoor air enters the car. This rate of airflow is known as the air change rate (A), and is a measure of the number of times fresh air replaces the indoor air in one hour. More specifically, according to ASTM ${ }^{15}$ the air change rate is the ratio of the total volume of air passing through the zone to and from the outdoors per unit of time to the volume of the zone.

To evaluate the performance of the fabric in terms of toxic gases exposure inside the vehicle, we performed two complementary studies. We first calculated the air change rate of the vehicle with and without the fabric over it to quantify the relative improvement in terms of protection from outside air when the fabric is used. The second study consisted in monitoring $\mathrm{CO}_{2}$ and $\mathrm{CO}$ inside the same vehicle when it was exposed to a fire and the fabric was covering it. The purpose of this test was to quantify concentrations reached inside the car and compare them against tenability values referred in the literature.

In both studies, we used a PS500 instrument (GMI Ltd.) to monitor gases inside the vehicle. Specifications about the sensors included in the instrument are shown in Table 4. Concentrations were recorded at a frequency of $1 \log$ every 10 seconds, except for the air change test performed with the fabric over the vehicle ( 1 log every 60 seconds).

\section{Air change tests}

We performed two tests to determine the air change rate of the vehicle: one test with the fabric deployed over it and another test without the fabric. To determine the air change rate we used the concentration decay procedure ${ }^{16,6}$. It consists in filling the vehicle with a target amount of tracer gas (in this case, $\mathrm{CO}_{2}$ ), and then monitor its decay. The gas concentration decays when fresh air with a lower or null gas concentration mixes with the air inside ${ }^{16}$. This decay can be fitted to Eq. 1 .

Where:

$$
C_{t}=C_{0} \cdot \exp (-A \cdot t) \quad \text { Eq. } 1
$$

$C_{t}$ is $\mathrm{CO}_{2}$ concentration at time instant $t(\% \mathrm{v}$. $)$

$C_{0}$ is $\mathrm{CO}_{2}$ concentration before concentration decay starts (\% v.)

$A$ is the air change rate $\left(\mathrm{s}^{-1}\right)$

$t$ is time instant (s)

We ensured that the vehicle windows and the vents were fully closed, and that the engine was turned off. Then we set up the vehicle with the PS500 instrument and a mixing fan, which could be controlled from outdoors and was used to ensure a better mixing. We gave a burst of gas from a bottle of liquefied $\mathrm{CO}_{2}$ through a partly opened door, then closed it immediately. We previously calibrated how much gas we could manually release in a controlled way.

Both tests lasted for about 30-60 minutes. The instrument was positioned at a height of around $0.8 \mathrm{~m}$ above vehicle's ground, hanging centered in the vehicle. A high initial concentration ( $>2 \% \mathrm{v}$.) was set to ensure that we would obtain sufficient sampling points given the resolution of the $\mathrm{CO}_{2}$ sensor.

\section{Exposure to combustion products}

An experimental burn was prepared similar to the one executed for assessing the performance of the fabric in terms of temperature increase inside the car. The main difference between both experimental burns was the humidity of the fuel. It was raining the days before this test, so the moisture content (in a dry basis $)$ of the fuel was high $(<6 \mathrm{~mm}$ size class: mean \pm s.d. $=34.6 \% \pm 4.3 \%$; $0.6 \mathrm{~cm}$ to $25 \mathrm{~cm}$ : mean \pm s.d. $=46.8 \% \pm 8.2 \%$ ). As stated by Simoneit $(2002)^{17}$, if the moisture content is $>30 \%$ combustion efficiency decreases, which in turn increases smoke formation. So calculated fuel moisture contents were considered adequate to reach dangerous conditions for the monitoring of gases inside the car. 


\section{RESULTS AND DISCUSSION}

\section{Heat exposure test}

\section{Environmental conditions and fuel moisture content}

The overall period under study comprised 40 minutes, from 11:40:00 to 12:20:00, being ignition time at 11:53:25. Mean ambient temperature recorded during the experiment was $27.6^{\circ} \mathrm{C}$ (s.d. $1.18^{\circ} \mathrm{C}$ ) and mean relative humidity was $59.2 \%$ (s.d. $4.32 \%$ ). The prevailing south-easterly wind had mean speed of $3 \mathrm{~m} / \mathrm{s}$ during the fire progression (s.d. $1.33 \mathrm{~m} / \mathrm{s}$ ). The induced air flow had a mean spead of 3 $\mathrm{m} / \mathrm{s}$ at $1.5 \mathrm{~m}$. Fuel moisture content (calculated at dry bases) was $26.7 \%$ (s.d. $8.4 \%$ ) for the lowest diameter class $(<6 \mathrm{~mm})$ and $26.2 \%$ (s.d. $5.7 \%$ ) for the highest $(0.6 \mathrm{~cm}$ to $2.5 \mathrm{~cm})$.

\section{Fire progression}

Fire spread was monitored as it progressed through zones A and B of the fuel bed. Drone imagery acquired from a nadir perspective was used to delineate fire progression isochrones every 30 seconds (Figure 4, a)). Isochrones were annotated manually and subsequently processed to compute fire rate of spread (ROS). Fire spread direction was assumed perpendicular to the fire perimeter, and ROS was estimated at every isochrone point as the distance travelled by fire in that direction divided by the time elapsed between consecutive isochrones. These point values were interpolated linearly to create a $2 \mathrm{D}$ ROS field (Figure 4, b)). ROS values obtained through this methodology are therefore spatially explicit and averaged over 30 seconds time intervals.

Measured fire spread direction was clearly aligned with induced wind, creating a pseudo-elliptical front (see isochrones \#3 and \#4) with maximum ROS values of $6 \mathrm{~m} / \mathrm{min}$. Average perimeter ROS varied with time between 1.3 and $2.7 \mathrm{~m} / \mathrm{min}$. In addition to surface spread, short-range spotting was observed (Figure 5).

Figure 4. a) Fire progression isochrones computed every 30 seconds; and b) resulting rate of spread (right). ROS field was interpolated linearly from point estimations obtained along every isochrone.

Figure 5. Aerial snapshot acquired $2 \mathrm{~min} 08 \mathrm{sec}$ after ignition, showing short-range spotting.

Figure 6. Video snapshot acquired $4 \mathrm{~min} 03 \mathrm{sec}$ after ignition, showing highest car exposure to flames.

Fire reached the fuel bed end approximately 3 minutes and 30 seconds after ignition (isochrone \#7), where flaming persisted for about 7.5 minutes. Maximum car exposure to flames occurred around 4 minutes after ignition (Figure 6). No direct contact between flame and fabric was observed. Finally, fuel zone $\mathrm{C}$ was ignited by fire brands 5 minutes after the start of the experiment, burning actively until all fuel was consumed.

\section{Fire line intensity}

Byram's fire line intensity ${ }^{18,19}$ was estimated according to previously computed ROS (mean values of $2.1 \mathrm{~m} / \mathrm{min}$ and $1.6 \mathrm{~m} / \mathrm{min}$, for Zone A and B, respectively) and following educated assumptions on the amount of fuel consumed by the flames. Fine fuel was assumed to be consumed completely during fire front residence time. Fine fuel loads were estimated to be $27.2 \mathrm{t} / \mathrm{ha}$ for zone A and $30 \mathrm{t} / \mathrm{ha}$ for zone B, according to fuel models described in ${ }^{20,21}$ for Pinus halepensis sapling stands. Measured fuel moisture content $(26.7 \%)$ and literature values for Pinus halepensis high calorific value $\left(20700 \mathrm{~kJ} / \mathrm{kg}^{22}\right)$ yielded average fire line intensities of $1500-1800 \mathrm{~kW} / \mathrm{m}$, with intensity peaks of up to $5100-5600 \mathrm{~kW} / \mathrm{m}$.

\section{Flame geometry}


Mean flame dimensions were computed by using image segmentation techniques ${ }^{23}$ (Figure 7). The period analysed covered the last $30 \mathrm{~s}$ of the fire progression and the first minute of continuous flaming at the interface between the Zone B and the fuel-cleared space. This time interval is representative of the highest fire exposure experienced by the protected vehicle. Flame geometry could hence be described by a flame height of around $6.5 \mathrm{~m}$ (mean value $6.38 \mathrm{~m}$, s.d. $1.22 \mathrm{~m}$ ), a tilt angle of $30^{\circ}$ (mean value $27.87^{\circ}$, s.d. $4.6^{\circ}$ ) and a flame depth of around $2 \mathrm{~m}$ (mean value $1.79 \mathrm{~m}$, s.d. $2.02 \mathrm{~m}$ ).

Figure 7. Segmentation process and flame geometry analysis. a) Visual image recorded by a video camera; b) flame segmentation; c) flame height analysis: the yellow line shows the vehicle contour, the blue dotted line goes from the basis of the vehicle to the highest flame point; d) flame tilt analysis; e) flame depth analysis.

\section{Estimation of flame temperatures, emissive power and radiative heat flux}

Brightness flame temperatures (subsequently corrected for emissivity $<1$ ) were assessed for the period of highest fire exposure by analysing IR imagery with Thermacam Researcher Pro 2.10 Software (Figure 8 ) to have an estimation of flame emissive power and incident radiative heat flux. Considering an emissivity of 0.7 for a $2 \mathrm{~m}$-depth flame ${ }^{24}$, and a distance of $8.4 \mathrm{~m}$ from the sensor to the flames, mean and maximum temperatures were obtained around $800^{\circ} \mathrm{C}$ (mean value of $772^{\circ} \mathrm{C}$, s.d. $47.6^{\circ} \mathrm{C}$ ) and 1200 ${ }^{\circ} \mathrm{C}$ (mean value of $1173{ }^{\circ} \mathrm{C}$, s.d. $52.3^{\circ} \mathrm{C}$ ) respectively. According to Stefan-Boltzmann law, mean flame emissive power was around $47.5 \mathrm{~kW} / \mathrm{m}^{2}$ with maximum values of $75.5 \mathrm{~kW} / \mathrm{m}^{2}$. Following the solid flame mode ${ }^{25}$ we estimated incident radiative heat fluxes both to the vertical and horizontal exposed surfaces of the car. We considered a $6-\mathrm{m}$ wide $6.5-\mathrm{m}$ height flame sheet tilted $30^{\circ}$ from the ground, whose base was separated $2.8 \mathrm{~m}$ from the car (according to Figure 1a and the above mentioned flame geometry descriptors). Following the algorithm described in Scarponi et al. ${ }^{26}$ we obtained mean view factors of 0.86 and 0.88 between the flame sheet and the vertical and horizontal exposed surfaces of the car, respectively (note that these high view factors confirm that the experimental fuel bed width was enough to replicate the conditions that would be obtained with wider fire lines). Assuming a unitary air transmissivity (note the reduced air space between the flame and the car in Figure 6), we obtained mean incident radiative heat fluxes between $41-42 \mathrm{~kW} / \mathrm{m}^{2}$ in both surfaces with maximum peaks of $65-66$ $\mathrm{kW} / \mathrm{m}^{2}$.

Figure 8. IR images of the period of highest fire exposure; a) beginning of the period; b) end of the period.

\section{Temperatures outside the fabric}

Figure 9 shows temperatures registered by the four thermocouples located outside the fabric. The effect of the heat emitted by the fire starts being noticed around 1:50 min after ignition. Maximum temperature values are observed between minutes 03:51 (maximum value of $137.6^{\circ} \mathrm{C}$ registered by thermocouple Te 4) and 05:02 (maximum value of $111.4{ }^{\circ} \mathrm{C}$ registered by thermocouple Te 2). The highest value recorded during this period is $201.5{ }^{\circ} \mathrm{C}$ at minute $04: 06$, corresponding to thermocouple Te 1 . This period coincides with the continuous presence of flames in the interface between the Zone $\mathrm{B}$ and the fuel-cleared space, where practically the whole width of the fuel is burning. These temperature values show that -at the location of the sensors- there was no direct contact of the flames with the thermocouples (the minimum temperature that can be expected for the presence of flames is about 350 ${ }^{\circ} \mathrm{C}^{27}$. After this period, there is a general temperature decreasing trend for the four thermocouples. This global decrease is, however fluctuating, i.e. peaks and valleys are observed all along the temperature evolution. These fire dynamics are consistent with the pulsating behaviour typically observed in wildfires ${ }^{28,29}$, due to intermittent fresh air indraft from the unburned fuel, producing a cooling effect. During the last minute (around 33 minutes after ignition), temperatures fluctuate between $31.7^{\circ} \mathrm{C}$ and $52.5^{\circ} \mathrm{C}$ (mean value of $43{ }^{\circ} \mathrm{C}$ ), being mean ambient temperature $31^{\circ} \mathrm{C}$ at that moment.

Figure 9. Temperature versus time evolution for the four thermocouples located outside the fabric. Initial 
time on the graph coincides with the ignition time.

\section{Temperatures in-between the fabric and the vehicle}

The effectiveness of the fabric as thermal insulator can be seen in Figure 10. The general trend is similar to the one reported in the previous section, although in this case the evolution is smoother and a few seconds delayed. Temperatures start to increase significantly 2.5 minutes after ignition (in the case of outside temperatures this increase was $40 \mathrm{~s}$ earlier) and reach a maximum between instant 04:24 (thermocouple $\mathrm{Tm} 1$ registers a maximum of $58.7^{\circ} \mathrm{C}$ ) and instant $4: 47$ (thermocouple $\mathrm{Tm} 2$ reaches $68.5^{\circ} \mathrm{C}$ ). In this period, the maximum temperature value recorded is $74.4{ }^{\circ} \mathrm{C}$ (by thermocouple $\mathrm{Tm} 3$, 04:43 min after ignition), with a delay of $37 \mathrm{~s}$ with respect to the maximum value recorded outside the fabric, and a value $63 \%$ lower. A similar fluctuating decreasing behaviour is also observed. In this case though, the pulse of the fluctuation is lower, both with respect to the frequency and to the temperature range. During the last minute, temperatures oscillate between $41.3{ }^{\circ} \mathrm{C}$ and $45^{\circ} \mathrm{C}$, with a mean value of $43.1^{\circ} \mathrm{C}$, almost equal to the outside temperature at the fabric registered during this period.

For a better comparison between outside fabric temperatures and the temperatures in-between the fabric and the vehicle, Figure 11 shows the temperature evolution for thermocouples Te 1 and Tm 3 . Both thermocouples recorded the highest temperature values of their zone (ZE for Te 1 and ZM for Tm).

Figure 10. Temperature vs time evolution for the three thermocouples located in-between the fabric and the vehicle. Initial time on the graph coincides with the ignition time.

Figure 11. Temperature vs time evolution for thermocouples Te 1 (located outside the fabric) and Tm 3 (located in-between the canvas and the vehicle).

\section{Temperatures inside the vehicle}

Temperature values registered by the thermocouples located inside the vehicle are shown in Figure 12. A significant difference can be observed between the temperature evolution of the thermocouple located in contact with the inside surface of the driver's window and the temperature evolution of all the other thermocouples, located at head's height on the front and back seat positions. Temperatures registered by the thermocouples located at the head's height increase monotonically five minutes after ignition. Maximum values are achieved 20 to 35 minutes after ignition. Table 5 shows the maximum values recorded which are around $41-42.5^{\circ} \mathrm{C}$. There are no significant differences between thermocouples due to their location. 35 minutes after ignition, a clear temperature decrease is observed. During the last minute, temperatures are very stable in all thermocouples and very similar to each other, with an average value of $39.2^{\circ} \mathrm{C}$ (s.d. $0.25^{\circ} \mathrm{C}$ ). Regarding the thermocouple located in contact with the driver's window, it registers a temperature increase 03:30 minutes after ignition, reaching a maximum value of $47.3{ }^{\circ} \mathrm{C}$ 08:55 minutes after ignition. From then on, it experiences a gentle descent until minute 33, after which the decrease becomes more pronounced.

Figure 13 shows the temperature evolution for thermocouples $\operatorname{Tm} 3$ and $\operatorname{Ti}$ 6, for a better comparison between temperatures recorded in-between the fabric and the vehicle and the temperatures recorded inside the vehicle, respectively. Both thermocouples recorded the highest temperature values of their zone (ZM for Tm 3 and ZI for Ti 6).

Figure 12. Temperature vs time evolution for the six thermocouples located inside the vehicle. Initial time on the graph coincides with the ignition time.

Figure 13. Temperature vs time evolution for thermocouples Tm 3 (located in-between the canvas and the vehicle) and Ti 6 (located inside the vehicle). 
Under the conditions of this experiment, temperature values reached inside the vehicle do not pose any risk to people. The limit for pain regarding ambient temperature is around $46{ }^{\circ} \mathrm{C}^{11}$. As reported, these values are never reached inside the vehicle. On the other hand, the limit for experiencing pain by heat conduction is set at $60{ }^{\circ} \mathrm{C}^{11}$. Temperatures on the window surface do not reach this threshold, so that contact with the glass would not cause damage to the occupants either.

\section{Gas exposure protection}

\section{Air change rate}

According to data recorded during the tests (Figure 14), the air change rate of the vehicle used to assess the performance of the fabric was estimated to be $0.006 \mathrm{~s}^{-1} \sim 2.1 \mathrm{~h}^{-1}(\mathrm{R}-\mathrm{sq}=0.99)$, which is in agreement with the values reported by Brown et al. $(2003)^{6}$. As expected, the air change rate of the vehicle when the fabric was deployed over it was lower $\left(0.0002 \mathrm{~s}^{-1} \sim 0.9 \mathrm{~h}^{-1} ; \mathrm{R}\right.$-sq $\left.=0.95\right)$. These values indicate that the fabric has a primary role in blocking exposure to outdoor contaminants because a lower air changing rate indicates that the airtightness of the vehicle was improved with the canvas.

Although the results from this test method apply to the specific conditions prevailing at the time of measurement, they are useful for our objective, i.e. to compare airtightness of the vehicle with and without the envelope of the canvas.

Figure 14. $\mathrm{CO}_{2}$ time evolution during air change tests (circles: vehicle without the fabric; crosses: vehicle with the fabric deployed over it) and their corresponding exponential fitted models.

\section{Gases evolution inside the vehicle}

As it is shown in Figure 15, the amount and color of the smoke observed during this experimental burn (grey and white, occupying a substantial volume) was much different to the one observed in Figure 6 (black and almost unnoticeable).

Figure 15. Photograph showing the amount and color of the smoke generated during the experimental burn executed to monitor gases.

Figure 16 shows the time evolution of $\mathrm{CO}_{2}$ and $\mathrm{CO}$ concentrations. The concentration of both gases inside the car significantly increased 20 minutes after the ignition and this was concurrent with the maximum thermal impact of the propagating flame front. The maximum concentration of $\mathrm{CO}_{2}$ registered inside the car was $0.13 \% \mathrm{v}$. (about 30 minutes after ignition); for $\mathrm{CO}$ the peak concentration registered was $79 \mathrm{ppm}$ (47 minutes after ignition).

The decreasing evolution for both gases was different. It was quite pronounced for $\mathrm{CO}_{2}$ but for $\mathrm{CO}$ it was hardly observable. This behavior indicates that $\mathrm{CO}_{2}$ inside the vehicle recovered gradually toward the initial value 33 minutes after ignition, when the flame front was extinguishing. On the contrary, an almost constant $\mathrm{CO}$ concentration was registered after the peak value, indicating that a stationary condition was reached during the interval between the peak value and the time when the recording was stopped. This may be due to the fact that incomplete combustion was still important during this period, when flames could hardly be observed.

Tenability values for both gases, according to Brown et al. $(2003)^{6}$, are $3 \% \mathrm{v}$. for $\mathrm{CO}_{2}$ and $100 \mathrm{ppm}$ for $\mathrm{CO}$ (worksafe short-term exposure level for 30 minutes). The same authors report that the first symptoms of CO poisoning (e.g. headache, fatigue) are observed between 50 and $100 \mathrm{ppm}$.

According to Figure 16 and the limiting values previously stated, tenable conditions were maintained during the whole test. Moreover, $\mathrm{CO}$ concentrations registered inside the car exceeded $70 \mathrm{ppm}$ for over 
40 minutes, implying that people inside would experience initial symptoms of low CO poisoning (e.g. headache) under the conditions of the test. This result is sensitive because in typically high intensity wildland fires, although we would expect a more complete combustion, i.e. lower $\mathrm{CO}$ values, the duration of the smoke exposure would be longer.

Figure 16. Time evolution of a) $\mathrm{CO}_{2}$ and b) $\mathrm{CO}$ during the fire exposure test.

\section{CONCLUSIONS}

The performance of a fabric specifically designed to protect people entrapped inside a vehicle during a wildfire has been investigated experimentally with two prescribed burns. The experiments were set-up to emulate heat and smoke exposure of surface fires of moderate intensity in case of car entrapment on a rural road. The monitoring methods used have allowed to characterize the fire, temperatures, and $\mathrm{CO}_{2}$ and $\mathrm{CO}$ concentrations inside the car (note that reported values should be taken as reasonable estimates because of the error associated with experimentation and uncertainty of the calculation methods).

Regarding the heat exposure test, fire rate of spread was around $2 \mathrm{~m} / \mathrm{min}$ with maximum values up to 6 $\mathrm{m} / \mathrm{s}$ and average fire intensities were around $1500-1800 \mathrm{~kW} / \mathrm{m}$ (with maximum values up to $5100-5600$ $\mathrm{kW} / \mathrm{m}$ ). Persistent flaming at the edge of the fuel bed where the vehicle was placed lasted 7.5 minutes, with a $1.5 \mathrm{~min}$ of highest exposure characterized by flames' height and depth around $6.5 \mathrm{~m}$ and $2 \mathrm{~m}$ respectively, tilted $30^{\circ}$ from the ground. Within this period, mean flame emissive power of $47.5 \mathrm{~kW} / \mathrm{m}^{2}$ with peaks up to $75.5 \mathrm{~kW} / \mathrm{m}^{2}$ resulted in incident radiative heat fluxes around $40 \mathrm{~kW} / \mathrm{m}^{2}$ in the exposed surfaces of the car, with maximum values of around $65 \mathrm{~kW} / \mathrm{m}^{2}$ (no flame contact was observed during the test). Maximum air temperatures inside the vehicle ranged around $41-42.5^{\circ} \mathrm{C}$, providing evidence of the fabric's good performance.

The experimental test to assess smoke exposure was prepared similar to the heat exposure test, but with more humid fuel $(>30 \%)$ to decrease combustion efficiency and hence favour the generation of smoke. In the conditions of the experiments described here, the effects on people due to the increase in temperature and $\mathrm{CO}_{2}$ and $\mathrm{CO}$ exposure would not be significant in adults in good health who were located inside the protected vehicle. Moreover, the fabric withstands the heat exposure tested without external damage and the intumescent layer does not react at these levels. The experiments prove that the fabric performs well to protect people from an eventual temperature increase inside the vehicle, and from $\mathrm{CO}_{2}$ and $\mathrm{CO}$ exposure, provided that the conditions to which the vehicle is exposed (in terms of radiant heat flux, exposure time and combustion efficiency), are similar or less critical than those tested in these experiments.

To analyse the response of the fire shelter fabric to more severe conditions in terms of heat flux exposure (i.e. higher radiant heat fluxes, longer duration), it would be necessary to perform new tests with an experimental set-up allowing to replicate more intense wildfire exposure. The response of the fire shelter fabric could also be evaluated in terms of other toxic compounds (e.g. particles and hydrogen chloride).

\section{ACKNOWLEDGEMENTS}

This work was supported by the Spanish Ministry of Economy and Competitiveness [Project CTQ201785990-R, funded with FEDER funds], the Autonomous Government of Catalonia [2017-SGR-392] and the Institut d'Estudis Catalans [project no. PR02018-S03] and the European Union Civil Protection (Project GA 826522 WUIVIEW UCPM-2018-PP-AG). 


\section{FIGURES}
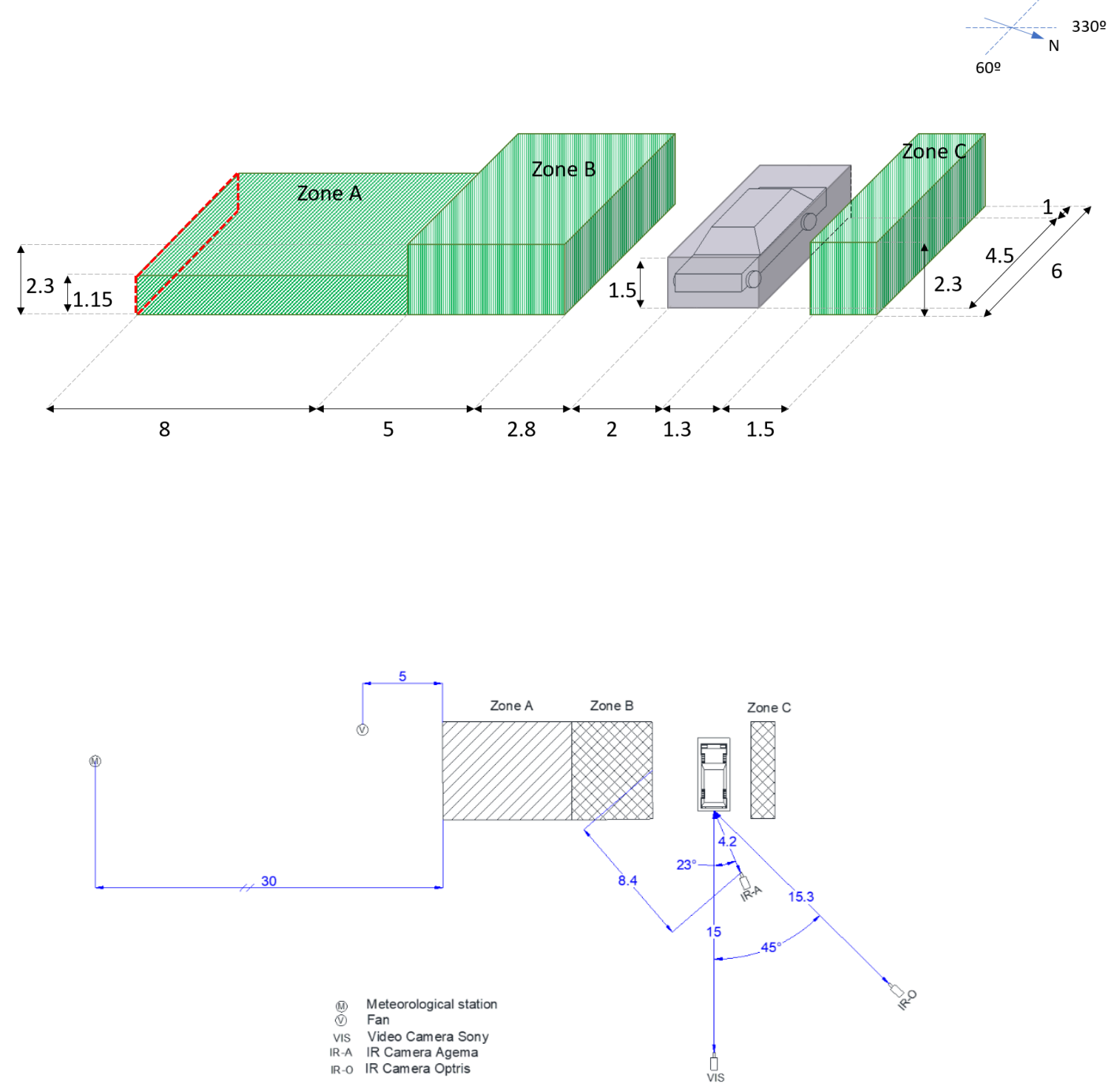

Figures 1A and 1B. 


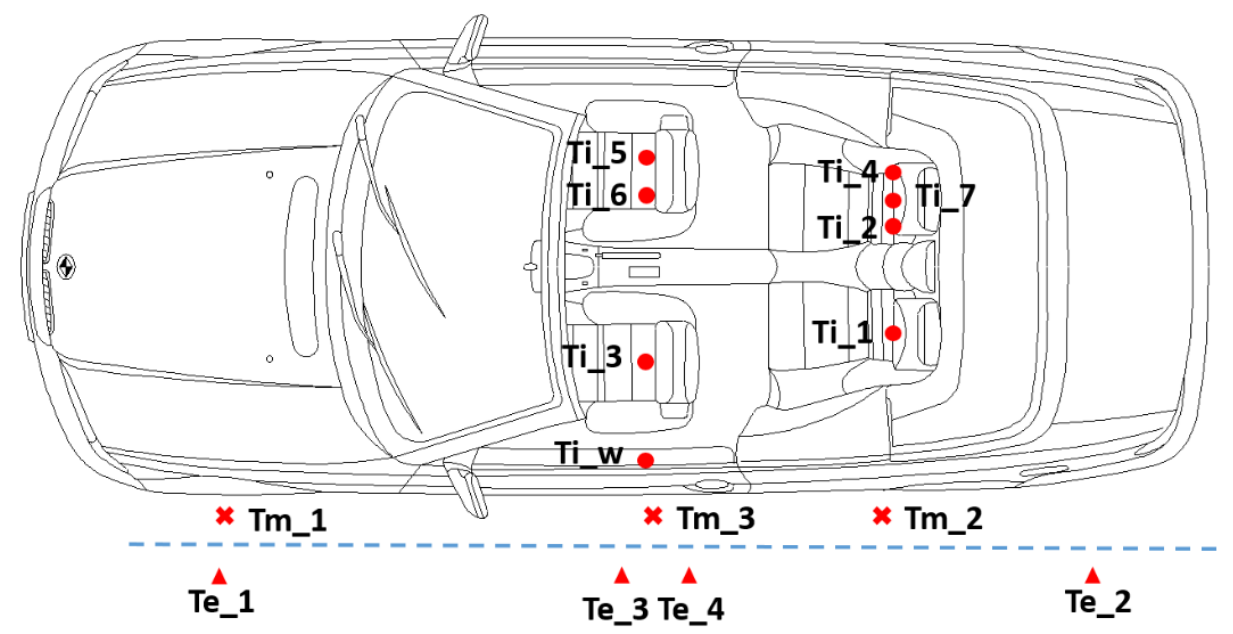

Figure 2
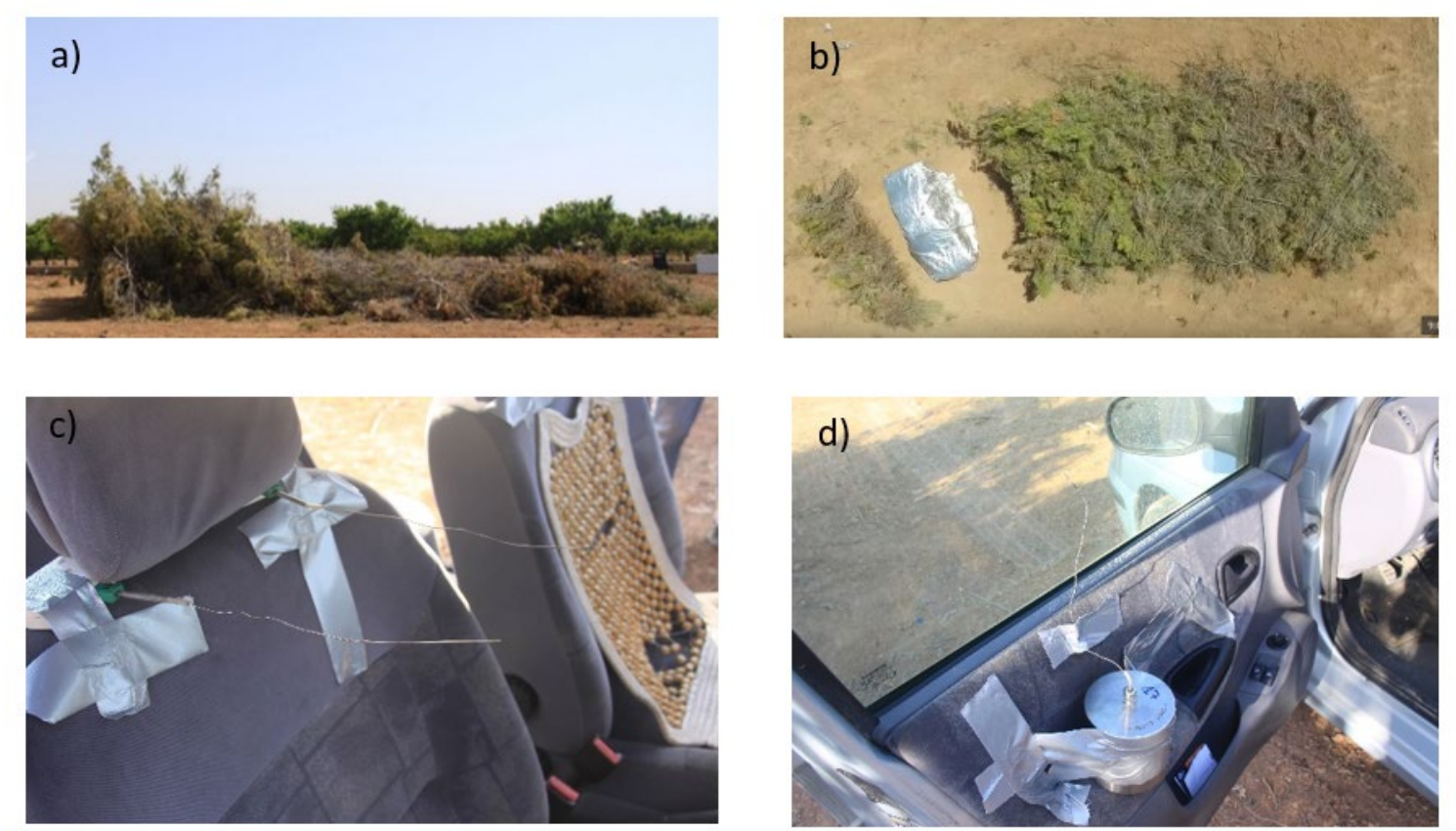

Figure 3
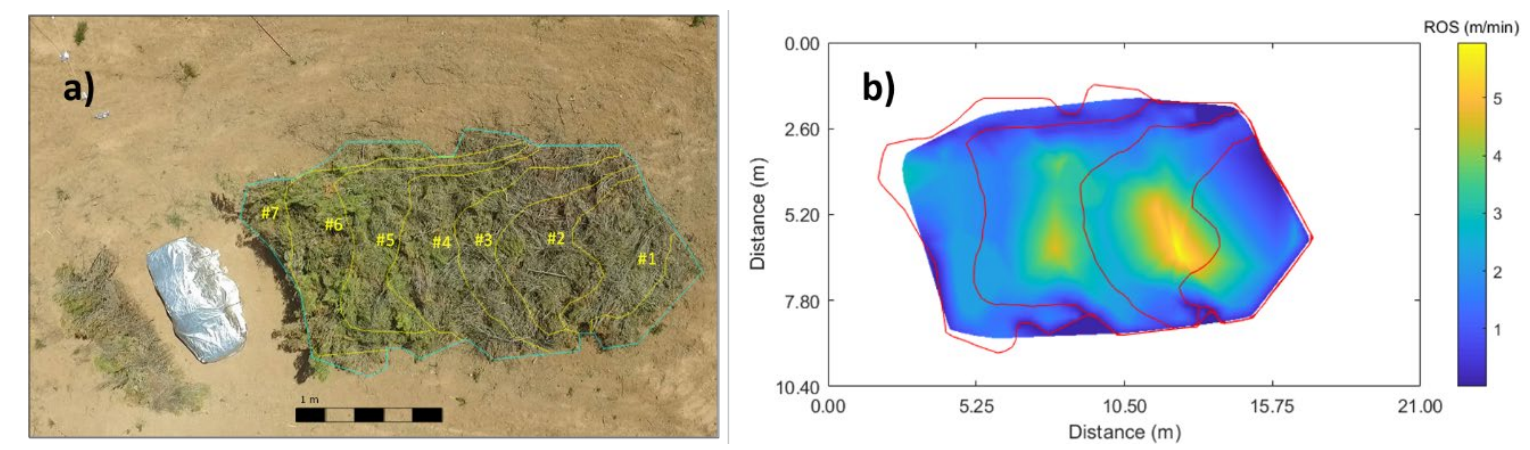

Figure 4 


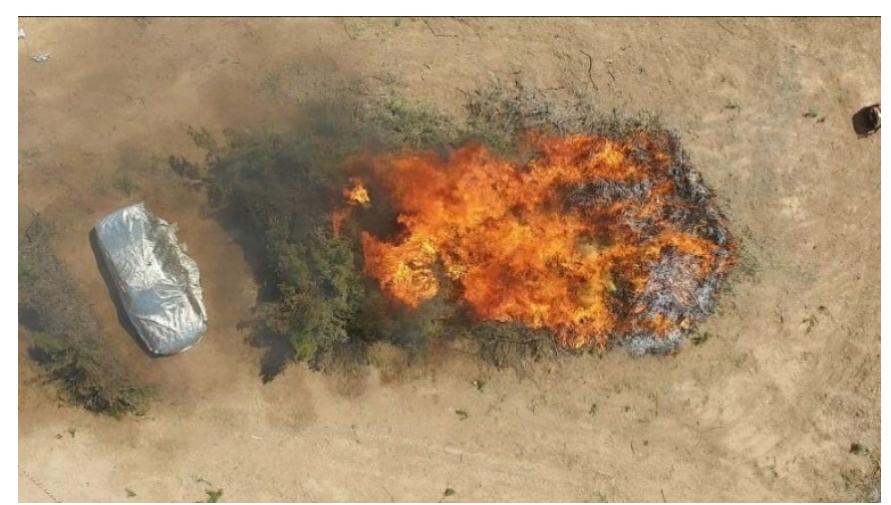

Figure 5

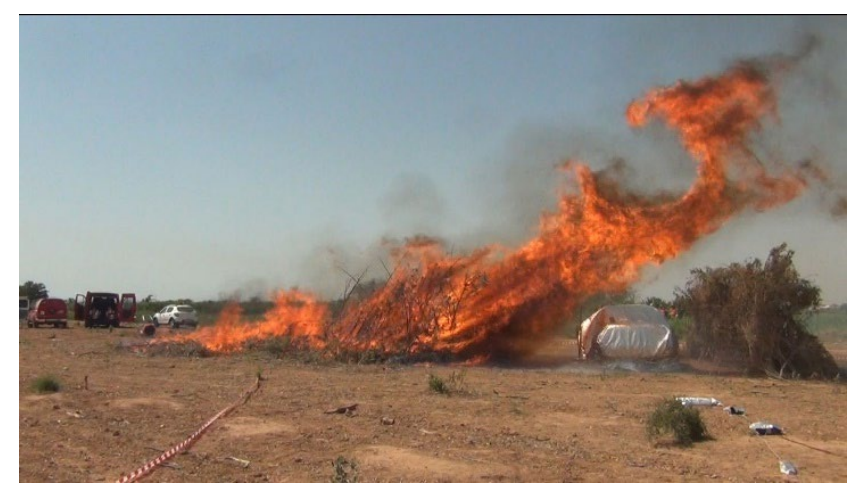

Figure 6

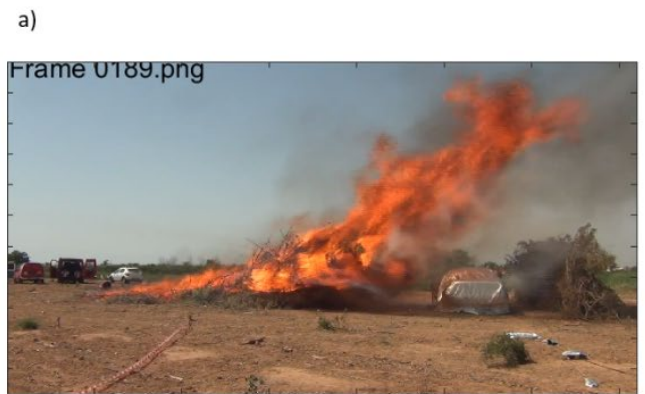

c)

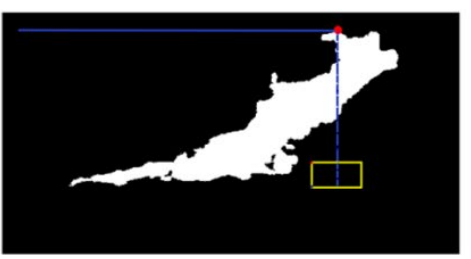

b)

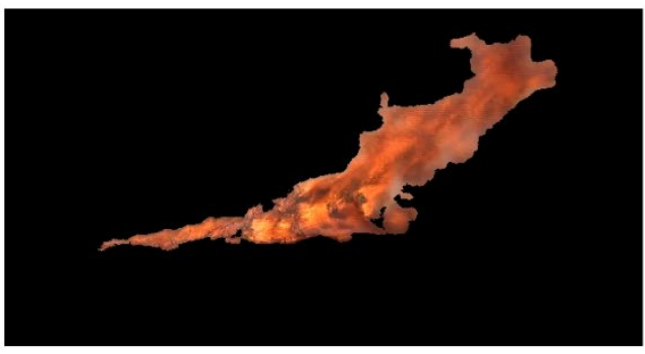

e)
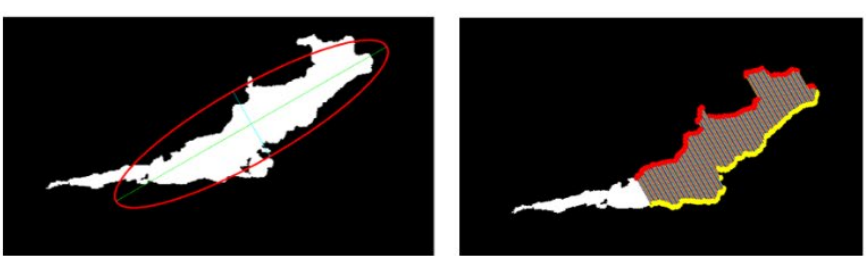

Figure 7 

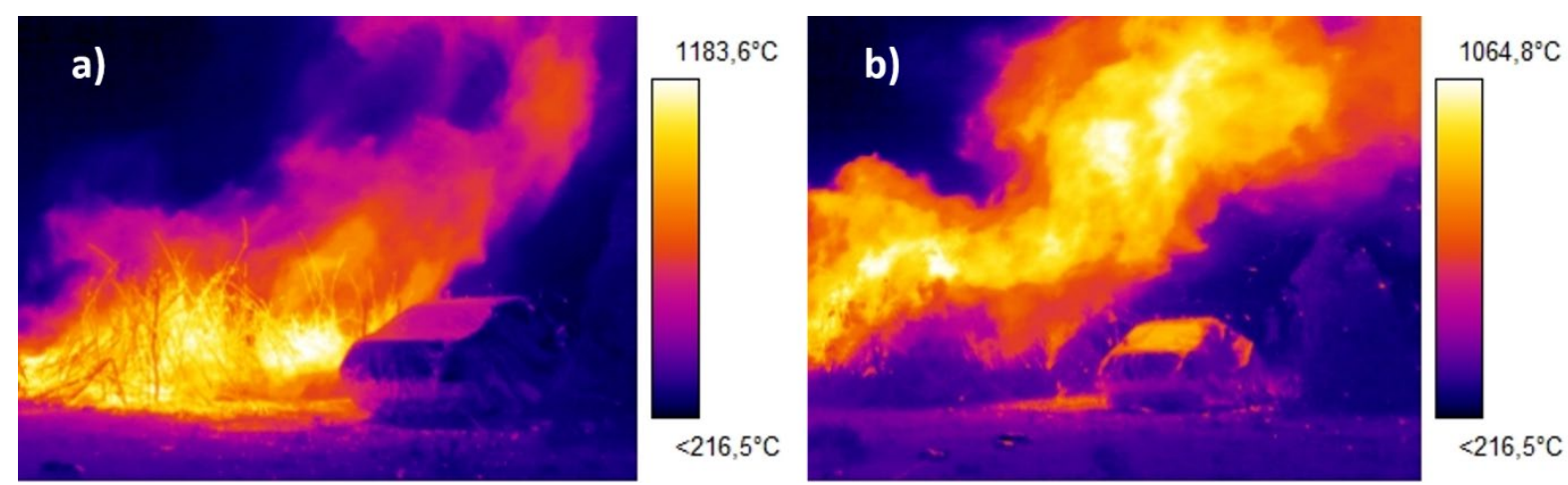

Figure 8

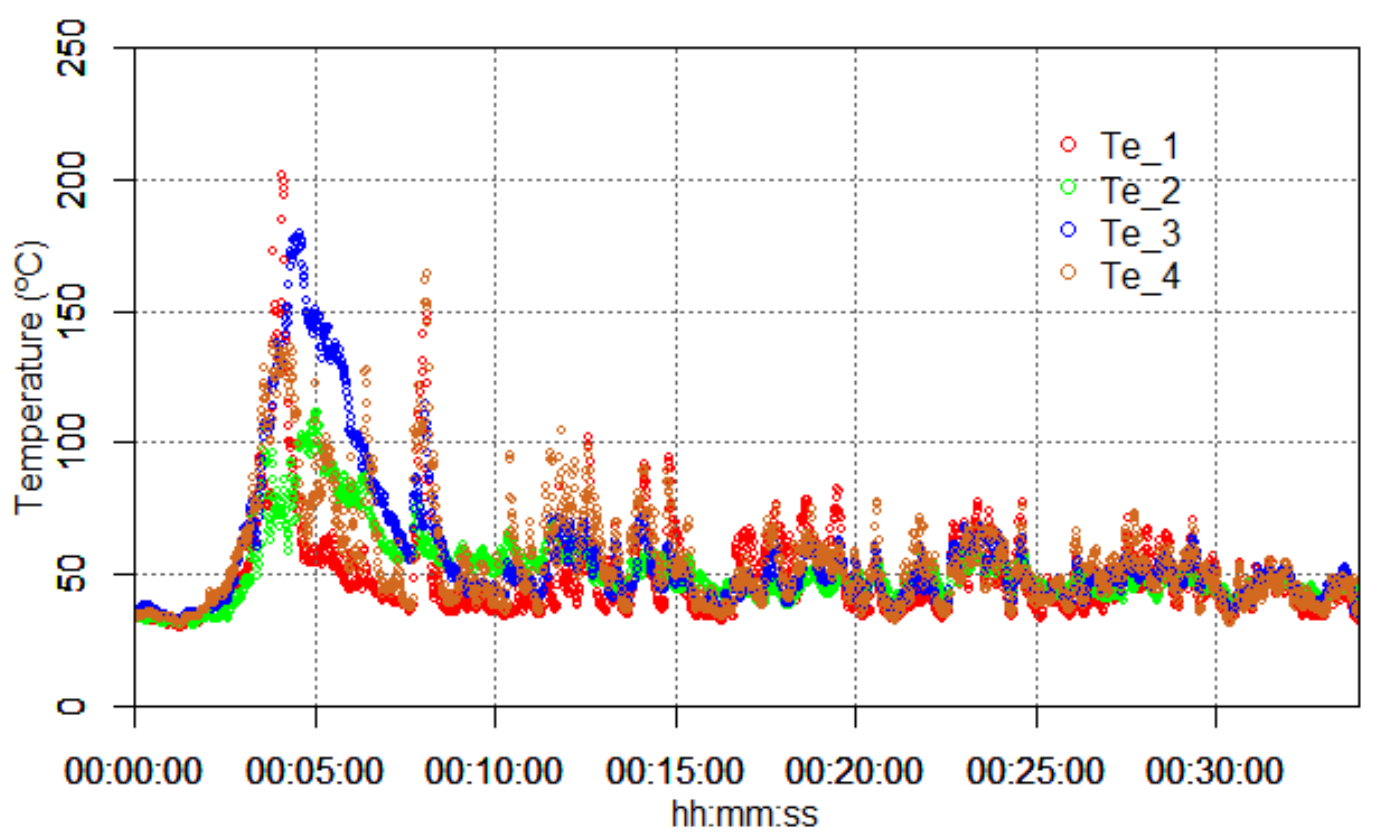

Figure 8 


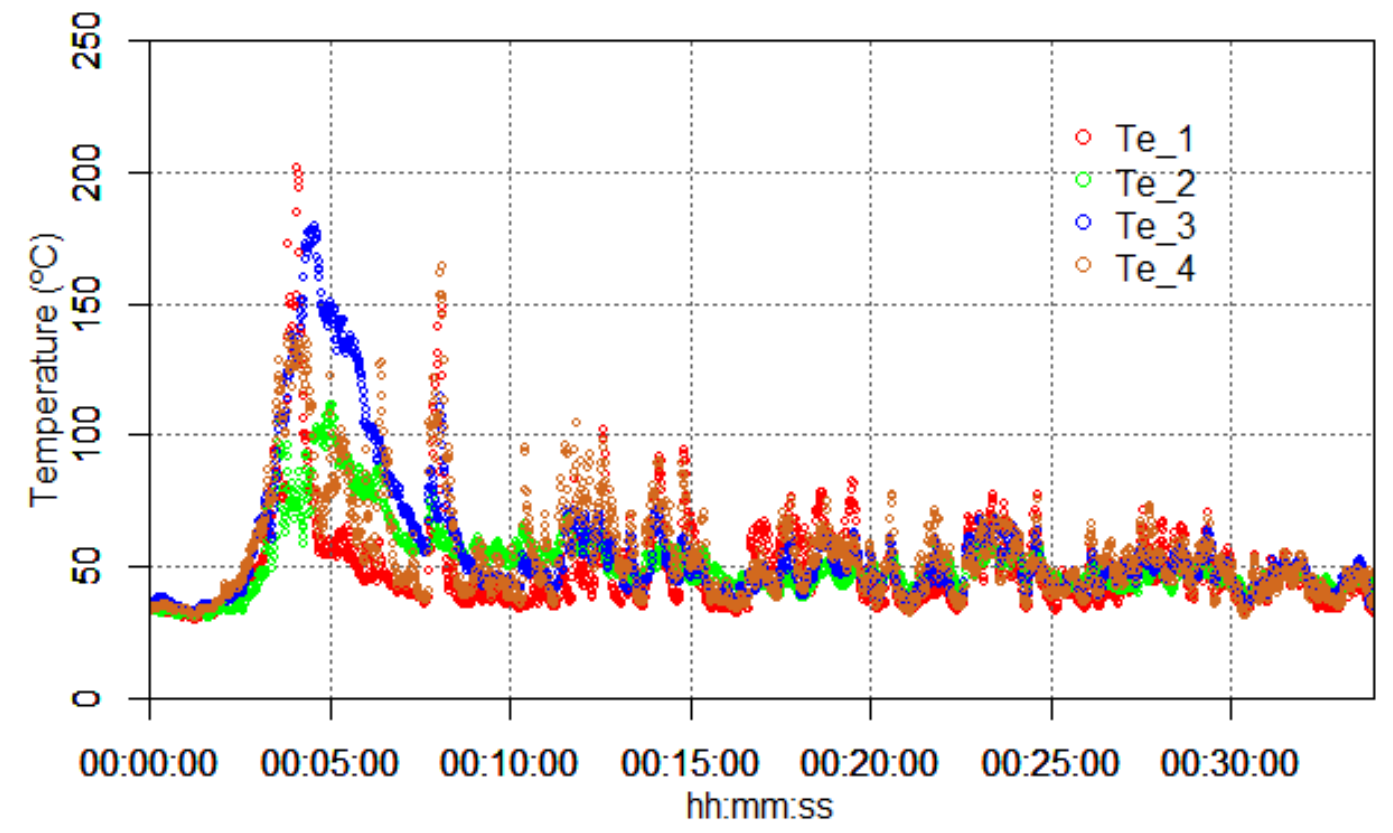

Figure 9

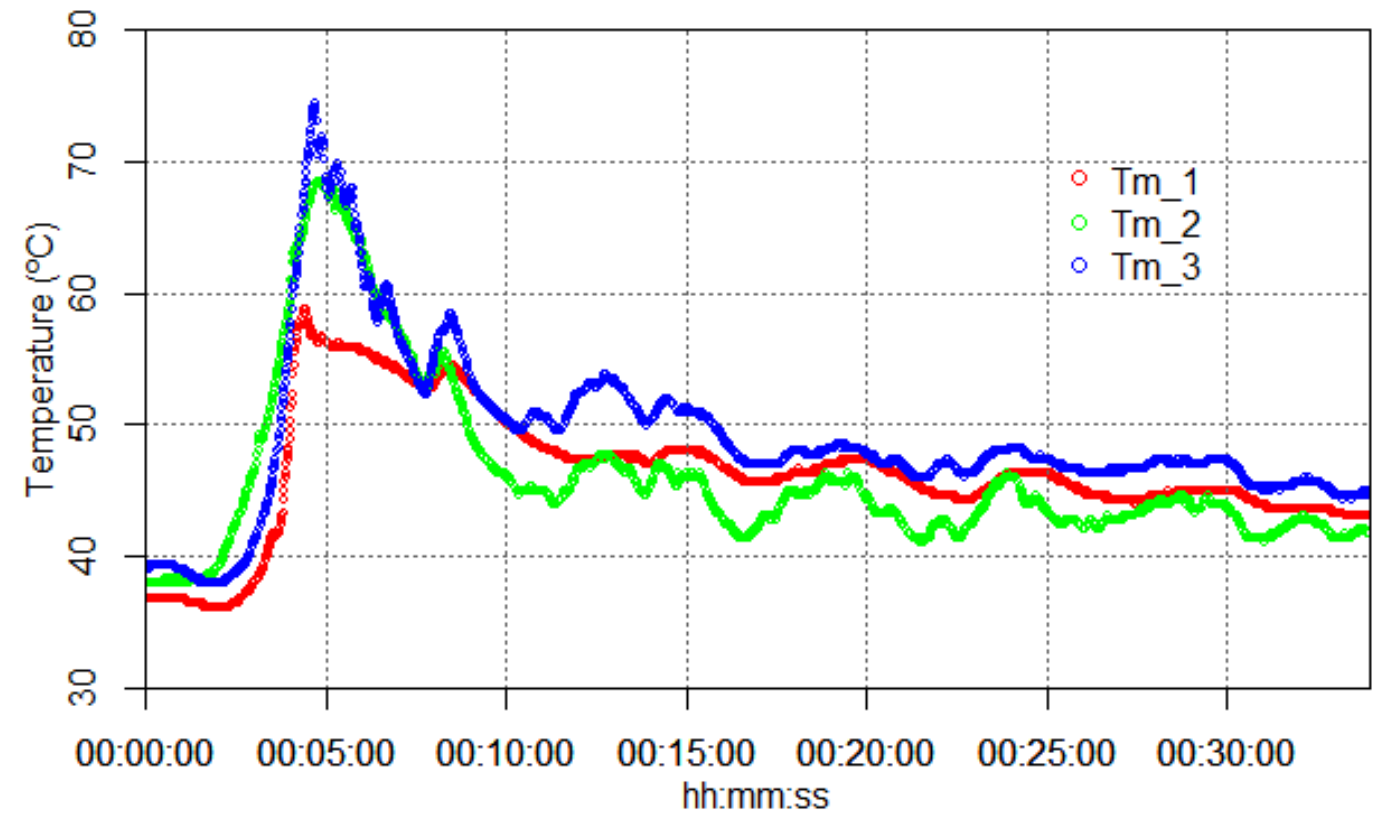

Figure 10 


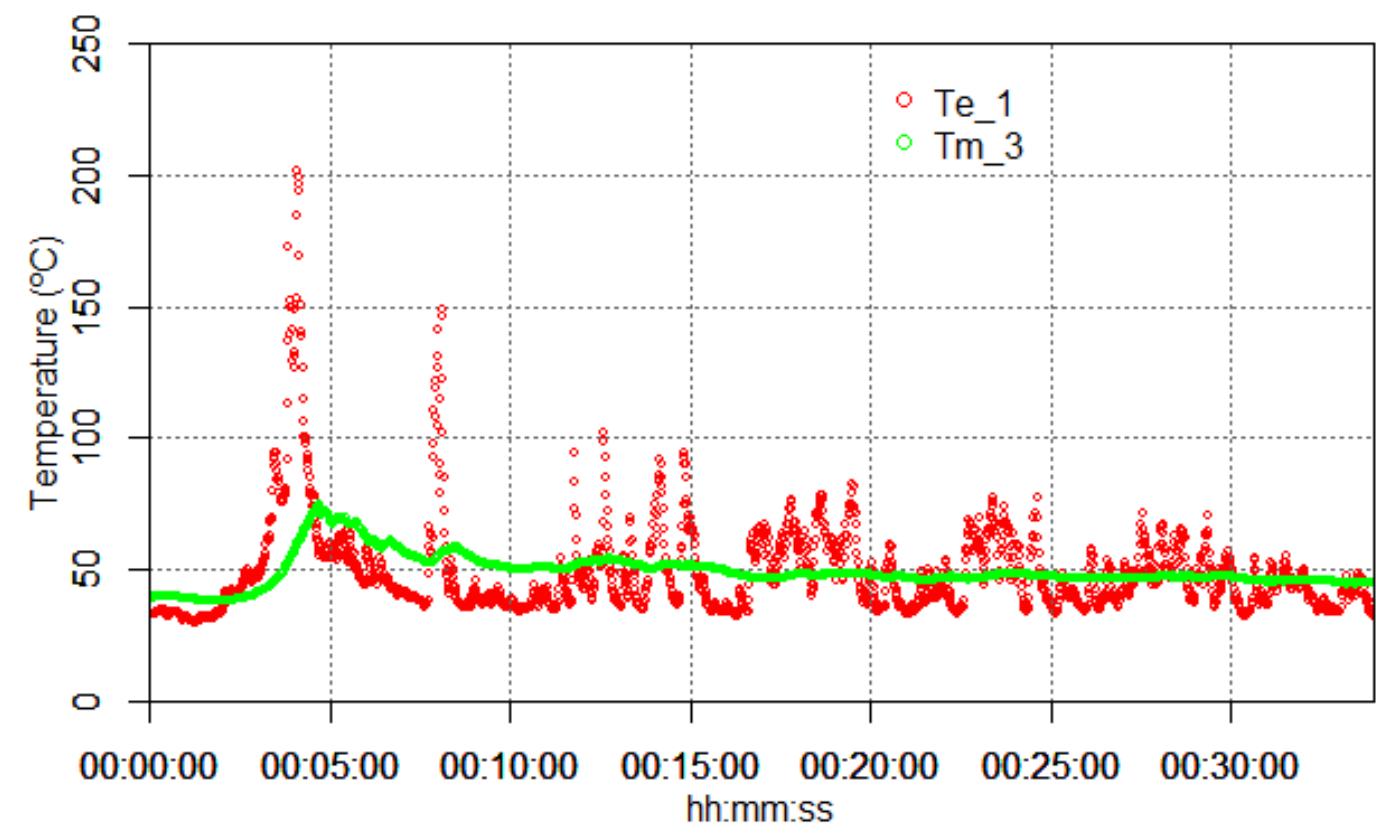

Figure 11

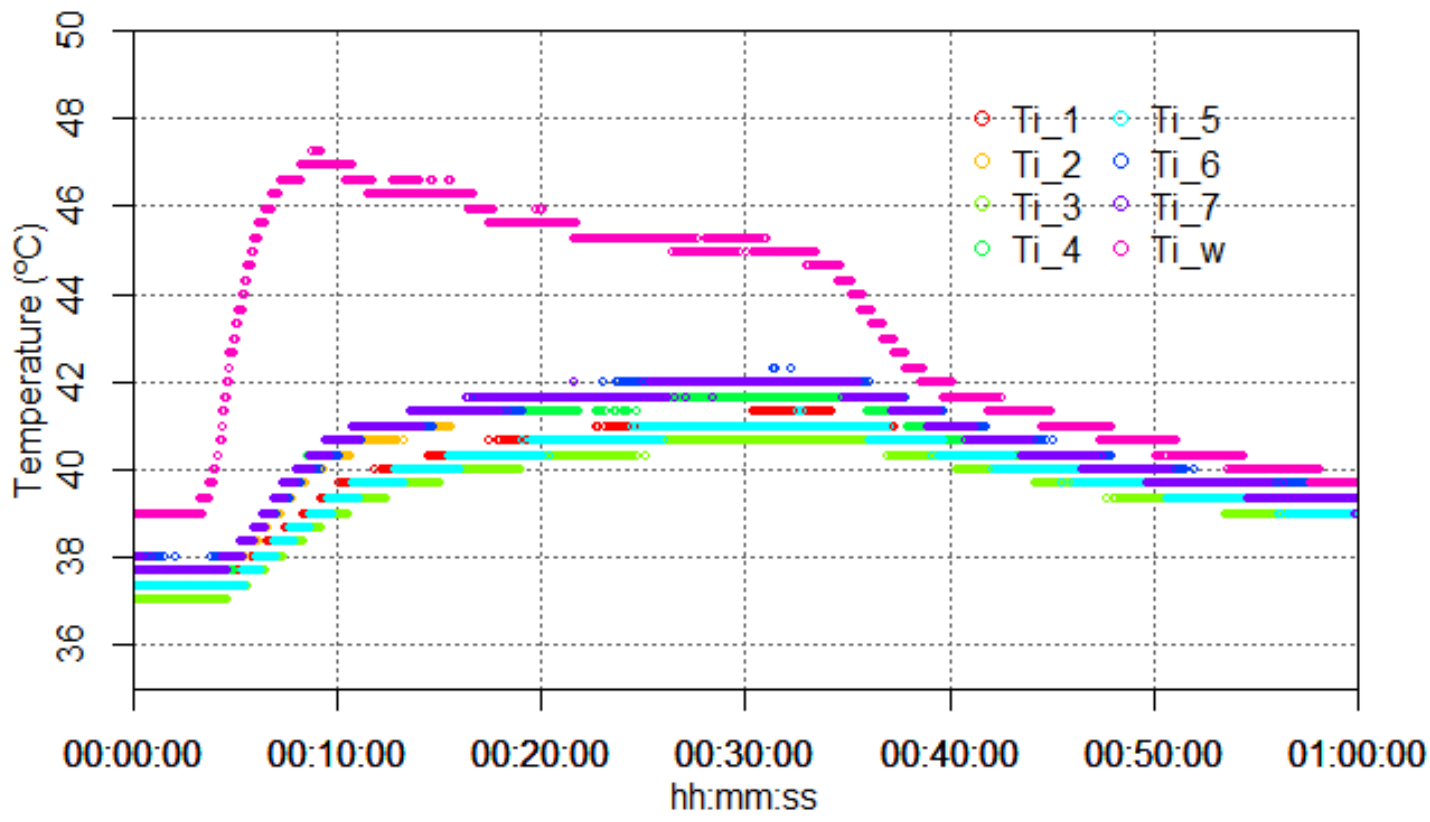

Figure 12 


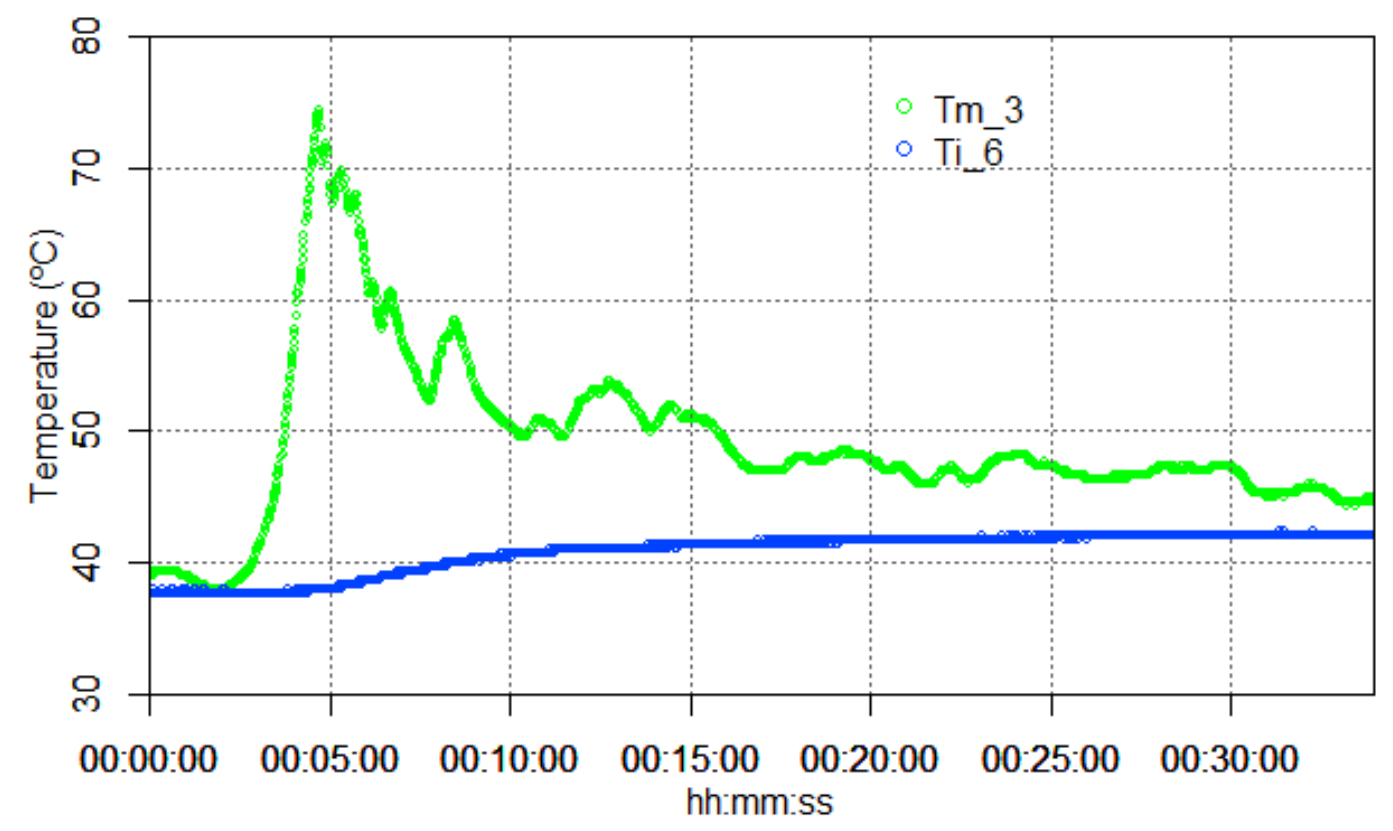

Figure 13

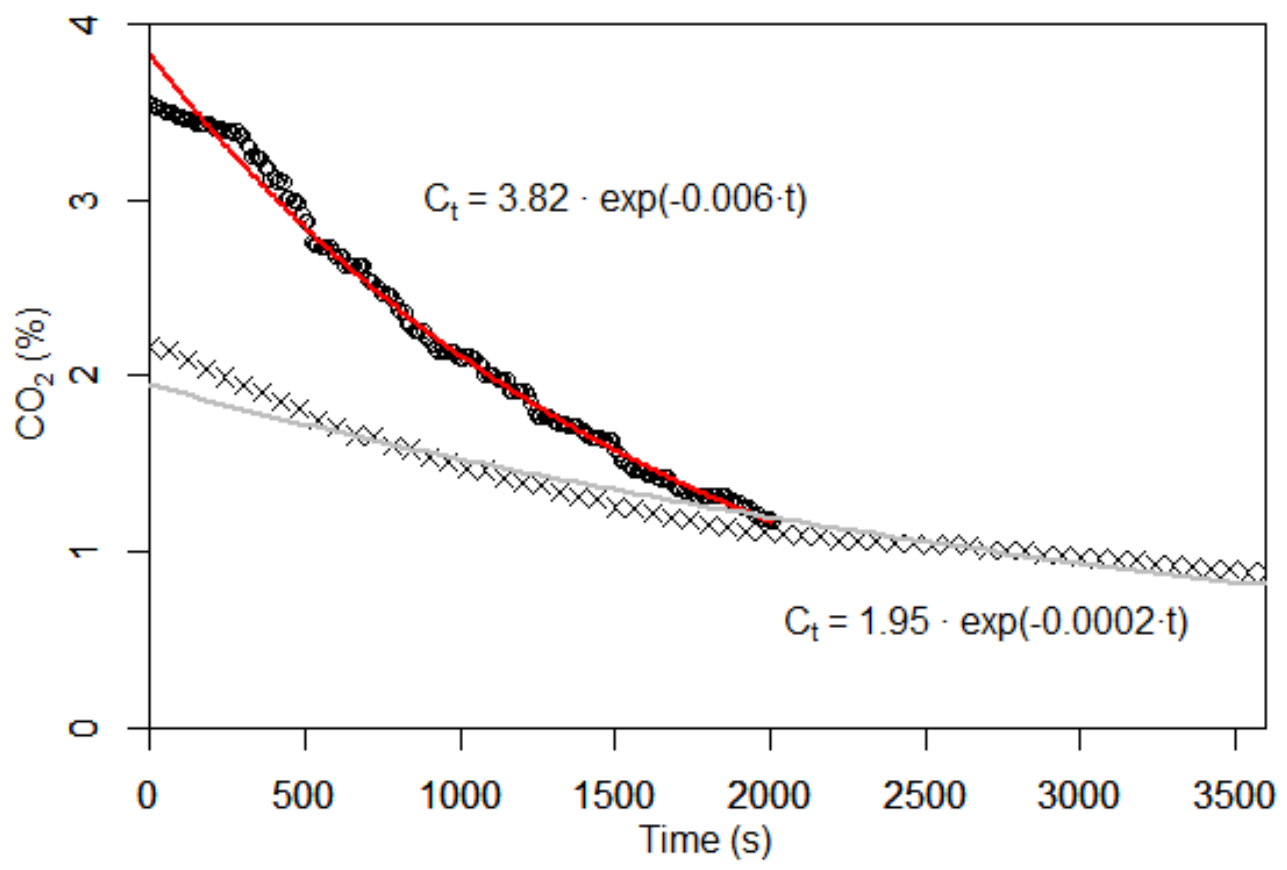

Figure 14 


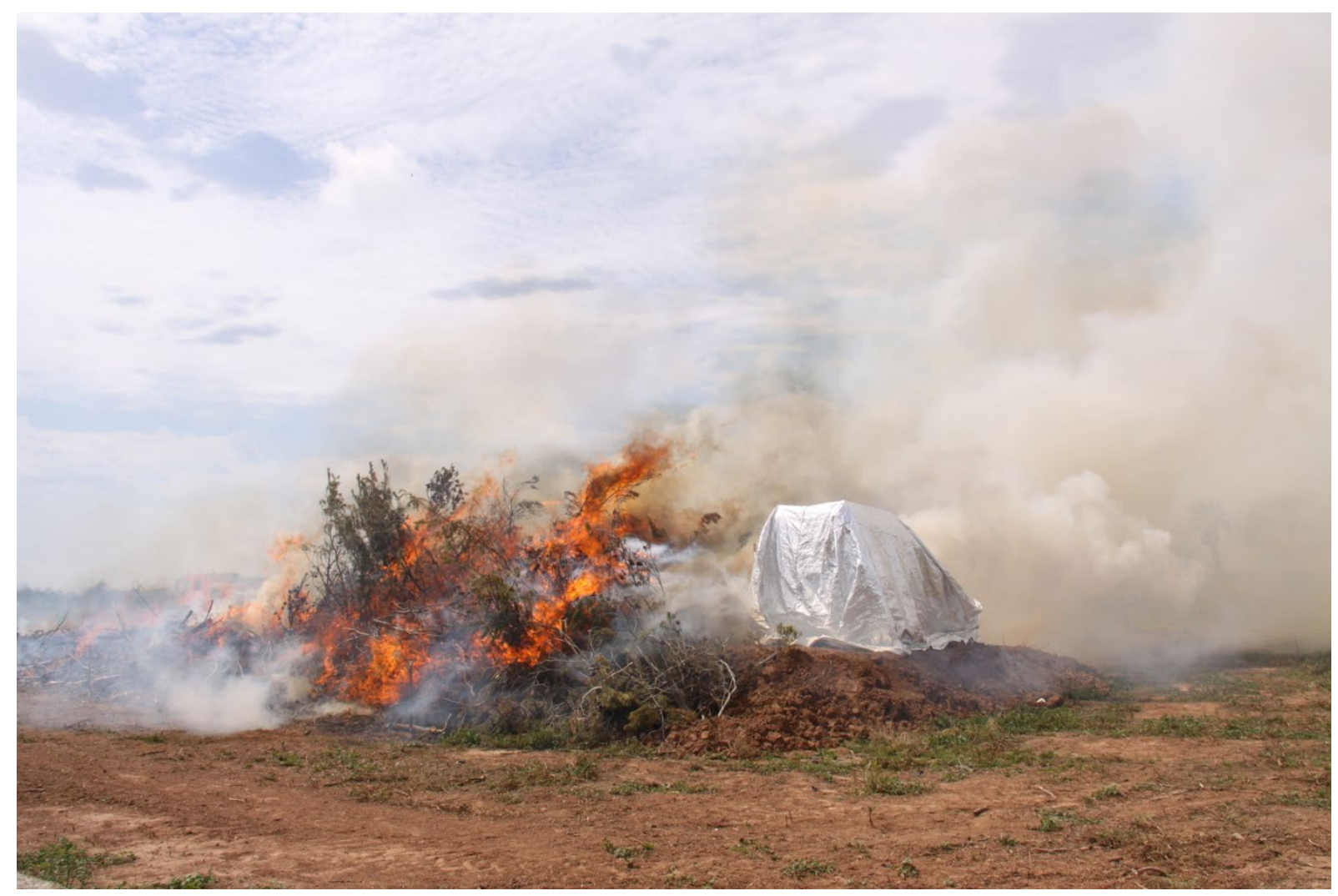

Figure 15
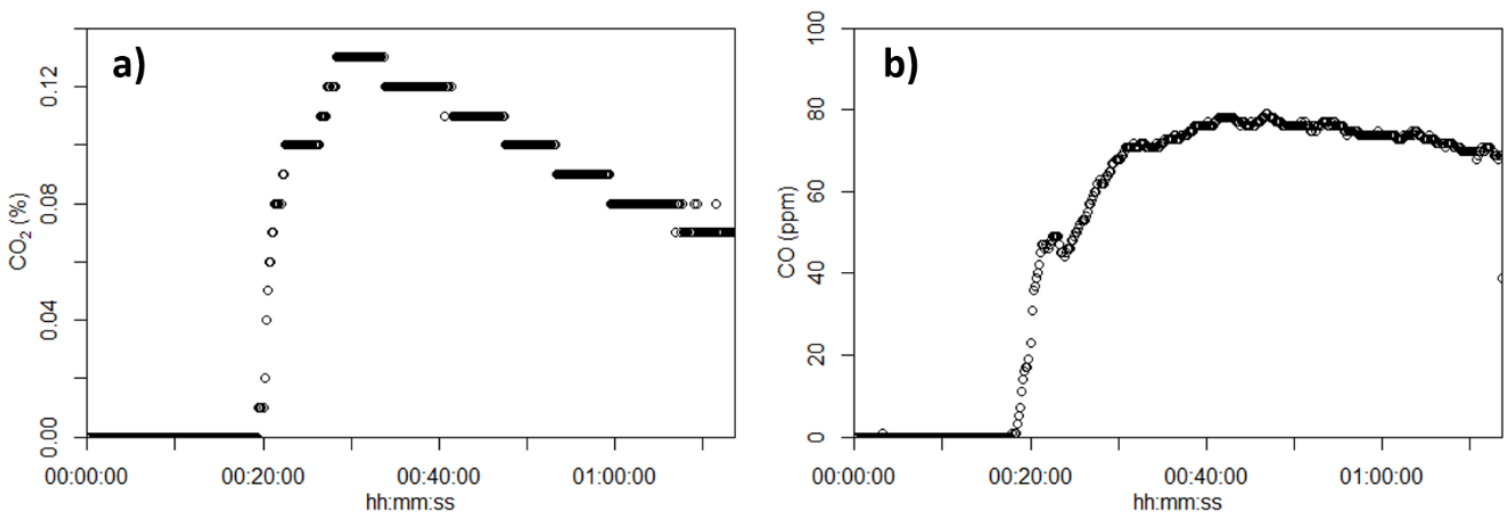

Figure 16

\section{REFERENCES}

${ }^{1}$ Butler, B., Putman, T. (2001). Fire shelter performance in simulated wildfires: an exploratory study. International Journal of Wildland Fire, 10, 29-44, doi: 10.1071/WF01019

2 Putman, T., Butler, BW. (2004). Evaluating fire shelter performance in experimental crown fires. Canadian Journal of Forest Research, 2004, 34(8): 1600-1615, doi: 10.1139/x04-091

${ }^{3}$ Takahashi, F. (2019). Whole-house fire blanket protection from wildland-urban interface fires. Frontiers in Mechanical Engineering, 5, article 60, doi: 10.3389/fmech.2019.00060

${ }^{4}$ Australasian Fire Authorities Council (AFAC) (2008). Guidelines for people in cars during bushfires. Available at: $\quad$ https://www.chillipreppers.com.au/uploads/5/9/5/1/5951747/fire-guidlines-people-in-vehicles.pdf. Accessed: September 5, 2019. 
${ }^{5}$ Mangan, R. (1998). Surviving fire entrapments: comparing conditions inside vehicles and fire shelters. Tech. Rep. 9751-2817-MTDC. Missoula, MT: US Department of Agriculture, Forest Service, Missoula Technology and Development Centre.

${ }^{6}$ Brown, S.K., Cheng, M., Mahoney, K.J., Leonard, J., Nichols, D., Canderle, A., Knight, I. (2003). Air toxics factors and criteria for crew survivability/tenability in vehicle burnover. 21st Annual conference of the Australian Institute of Occupational Hygienists, "Improving occupational hygiene in small business", Dec. 6-10, 2003, Adelaide, Australia

${ }^{7}$ Knight et al. (2003). Thermal factors for human survival in fire tanker burn-overs. Presented to 3rd International Wildland Fire Conference, 3-6 October, Sydney, Australia

${ }^{8}$ Sargeant, A., Brown, S., Leonard, J., Blanchi, R. (2007). Civilian passenger vehicle burnover experimentation. Paper presented to 2007 Joint AFAC/Bushfire CRC Conference

${ }^{9}$ NEWS (2015) https://www.abc.net.au/news/2015-06-28/wa-volunteer-firefighter-develops-fireshield/6578956. Accessed: September 5, 2019

${ }^{10}$ eldiario.es (2019) https://www.eldiario.es/sociedad/Inventan-sintetica-salvar-incendiosforestales_0 881911998.html. Accessed: September 5, 2019

${ }^{11}$ Bradshaw, V. (2006). The building environment: active and passive control systems. John Wiley and Sons.

${ }^{12}$ Rothermel, R.C., 1972. A mathematical model for predicting fire spread in wildland fuels. USDA Forest Service, Intermountain Forest \& Range Experiment Station. Res. Pap. INT-115.

${ }^{13} \mathrm{Scott}$ and Burgan (2005). Standard fire behaviour fuel models: a comprehensive set for use with Rothermel's surface fire spread model. USDA Forest Service, Rocky Mountain Research Station. Gen Tech Rep, RMRSGTR-153.

${ }^{14}$ DWG models. Free DWG. https://dwgmodels.com/567-set-of-cars.html. Accessed: February 11, 2020.

${ }^{15}$ ASTM International (2017). Standard test method for determining air change in a single zone by means of a tracer gas dilution. Designation: e741-11 (Reapproved 2017)

${ }^{16}$ Montoya, I., Pastor, E., Planas, E. (2011). Air infiltration in Catalan dwellings and sealed rooms: An experimental study. Building and environment, 4(10), 2003-2011. https://doi.org/10.1016/j.buildenv.2011.04.009

${ }^{17}$ Simoneit, B. (2002). Biomass burning - a review of organic tracers for smoke from incomplete combustion. Applied Geochemistry, 17(3), 129-162. https://doi.org/10.1016/S0883-2927(01)00061-0

${ }^{18}$ Byram, G.M. (1959). Combustion of forest fuels. In: Forest fire control and use. Davis KP, McGraw-hill Book Co, New York.

${ }^{19}$ Alexander, M.E. (1980). Calculating and interpreting forest fire intensities. Canadian Journal of Botany, 60, 349357.

${ }^{20}$ Domènech, R. (2011). Efectivitat dels tractaments d'aclarida en la reducció del risc de propagació d'incendis en regenerats de pi blanc. PhD Thesis. Universitat Politècnica de Catalunya. $235 \mathrm{pp}$

${ }^{21}$ Domènech, R., Pastor, E., Àgueda, A., Sans, A., Navascués, P., Planas, E. (2013). Modelos de combustible para caracterizar el comportamiento de los incendios en regenerados clareados de pino carrasco. Montes, 115, 22-29.

${ }^{22}$ Guijarro, M., Hernando, C., Díez, C., Martínez, E., Madrigal, J., Lampin, C., Blanc, L...Fonturbel, M. (2002). Flammability of some fuel beds common in the South-European ecosystems. En: D.X. Viegas (Ed.), Forest Fire Research and Wildland Fire Safety, Millpress, Rotherdam, 1-9.

${ }^{23}$ Mata, C., Pastor, E., Rengel, B., Valero, M., Planas, E., Palacios, A. and Casal, J. (2018). Infrared Imaging Software for Jet Fire Analysis. The Italian Association of Chemical Engineering (AIDIC), ISBN 978-88-9560864-8, Vol. 67.

${ }^{24}$ Àgueda, A., Pastor, E., Pérez, Y., Planas, E. (2010). Experimental study of the emissivity of flames resulting from the combustion of forest fuels. International Journal of Thermal Sciences, 49(3), 1-12.

${ }^{25}$ Eisenberg, N.A., Lynch, C.J., Breeding, R.J. (1975). Vulnerability model. A simulation system for assessing damage resulting from marine spills. Final report.

${ }^{26}$ Scarponi, G.E., Landucci, G., Heymes, F., Cozzani, V. (2018). Experimental and numerical study of the behaviour of LPG tanks exposed to wildland fires. Process Safety and Environmental Protection, 11, 251-270.

${ }^{27}$ Babrauskas, V. (2006). Temperatures in flames and fires. Fire Science and Technology Inc. San Diego, CA.

${ }^{28}$ Frankman, D., Webb, B. W., Butler, B. W., Jimenez, D., Forthofer, J. M., Sopko, P., Ottmar, R. D. (2013). Measurements of convective and radiative heating in wildland fires. International Journal of Wildland Fire, 22(2), 157-167.

${ }^{29}$ Tang, W., Gorham, D. J., Finney, M. A., Mcallister, S., Cohen, J., Forthofer, J., \& Gollner, M. J. (2017). An experimental study on the intermittent extension of flames in wind-driven fires. Fire Safety Journal, 91, 742748.

${ }^{30}$ US Consumer Product Safety Commission (2009) CO questions and answers. https://www.cpsc.gov/SafetyEducation/Safety-Education-Centers/Carbon-Monoxide-Information-Center/Carbon-Monoxide-Questions-andAnswers. Accessed: September 5, 2019 


\section{TABLES}

Table 1. Experimental studies performed to test fire shelters, firefighters engines and civilian cars performance against fire. NA: Not available.

\begin{tabular}{|c|c|c|c|c|c|}
\hline Study & Specimens & $\begin{array}{c}\text { System for } \\
\text { protecting } \\
\text { the vehicle } \\
\text { cabin }\end{array}$ & $\begin{array}{c}\text { Inside } \\
\text { measurements }\end{array}$ & $\begin{array}{c}\text { Fire source } \\
\text { (intensity) }\end{array}$ & $\begin{array}{c}\text { Maximum } \\
\text { Heat flux }\end{array}$ \\
\hline $\begin{array}{l}\text { Sargeant } \\
\text { et al. } \\
(2007)^{8}\end{array}$ & $\begin{array}{l}\text { Used cars in } \\
\text { operable } \\
\text { conditions }\end{array}$ & - & $\begin{array}{c}\text { Respirable } \\
\text { particles, CO, HCL, } \\
\text { HCN } \\
\text { Temperature } \\
\text { Total heat flux }\end{array}$ & $\begin{array}{l}\text { LPG gas-fired } \\
\text { grid (NA) }\end{array}$ & $\begin{array}{c}0.028-1.7 \\
\mathrm{~kW} / \mathrm{m}^{2} \\
\text { (inside, } \\
\text { below } \\
\text { window) }\end{array}$ \\
\hline $\begin{array}{l}\text { Brown et } \\
\text { al. }(2003)^{6}\end{array}$ & $\begin{array}{l}\text { Firefighting } \\
\text { vehicles }\end{array}$ & $\begin{array}{c}\text { Radiation } \\
\text { shields or } \\
\text { watersprays }\end{array}$ & $\begin{array}{c}\text { Respirable } \\
\text { particles, } \mathrm{CO}, \mathrm{HCl}, \\
\text { formaldehyde, } \\
\text { TVOC }\end{array}$ & $\begin{array}{l}\text { LPG gas-fired } \\
\text { grid }(5-10 \\
\mathrm{MW} / \mathrm{m})\end{array}$ & NA \\
\hline $\begin{array}{l}\text { Knight et } \\
\text { al. }(2003)^{7}\end{array}$ & $\begin{array}{l}\text { Firefighting } \\
\text { trucks }\end{array}$ & $\begin{array}{c}\text { Radiation } \\
\text { shields, } \\
\text { watersprays } \\
\end{array}$ & $\begin{array}{c}\text { Temperature } \\
\text { Radiant heat flux }\end{array}$ & $\begin{array}{l}\text { LPG gas-fired } \\
\text { grid }(2.5-10 \\
\mathrm{MW} / \mathrm{m})\end{array}$ & $\begin{array}{l}0.5-10 \\
\mathrm{~kW} / \mathrm{m}^{2} \\
\text { (inside) }\end{array}$ \\
\hline $\begin{array}{l}\text { Mangan } \\
(1998)^{5}\end{array}$ & $\begin{array}{l}\text { Firefighting } \\
\text { vehicles and } \\
\text { fire shelters }\end{array}$ & - & $\begin{array}{c}\text { Particles, } \mathrm{HCl} \text {, } \\
\text { HCN, SO2, } \\
\text { Benzene, toluene, } \\
\text { CO } \\
\text { Temperature } \\
\text { Radiant heat flux }\end{array}$ & $\begin{array}{l}\text { Grass, brush } \\
\text { or timber fuel } \\
\text { (NA) }\end{array}$ & $\begin{array}{c}70-150 \\
\mathrm{~kW} / \mathrm{m}^{2} \\
\text { (outside) }\end{array}$ \\
\hline
\end{tabular}

Table 2. Infrared cameras specifications

\begin{tabular}{|l|l|l|}
\hline Equipment & $\begin{array}{l}\text { AGEMA Thermovision 570 }- \\
\text { Pro (FSI FLIR Systems) }\end{array}$ & $\begin{array}{l}\text { Thermal Imager Optris Pi 640 } \\
\text { (OPTRIS) }\end{array}$ \\
\hline Detector & $\begin{array}{l}\text { FPA (Focal Plane Array), non- } \\
\text { refrigerated microbolometer }\end{array}$ & $\begin{array}{l}\text { FPA (Focal Plane Array), non- } \\
\text { refrigerated microbolometer }\end{array}$ \\
\hline Brightness temperature range $\left(^{\circ} \mathbf{C}\right)$ & $-20-1500$ & $-20-900$ \\
\hline Thermal sensitivity $\left.\mathbf{~}^{\circ} \mathbf{C}\right)$ & 0.15 & 0.075 \\
\hline Field of view $\left.\mathbf{(}^{\circ}\right)$ & $24^{\circ} \times 18^{\circ}$ & $60^{\circ} \times 45^{\circ}$ \\
\hline Spectral range $(\boldsymbol{\mu m})$ & $7.5-13$ & $7.5-13$ \\
\hline Image size & $320 \times 240$ pixel & $640 \times 480$ pixel \\
\hline Operation mode & Discontinuous & Continuous recording $(32 \mathrm{fps})$ \\
\hline
\end{tabular}

Table 3. Thermocouples location

\begin{tabular}{|l|l|l|}
\hline ID Zone & Description & Thermocouples numbering \\
\hline ZI & $\begin{array}{l}\text { Vehicle inside. Thermocouples placed at head's } \\
\text { height (seated passengers) }\end{array}$ & $\begin{array}{l}\text { Driver space: Ti 3 } \\
\text { Copilot space: Ti 5 and Ti 6 } \\
\text { Backseat (rear driver) space: Ti 1 } \\
\text { Backseat (rear copilot) space: Ti 4, Ti 7 and Ti } 2 . \\
\text { Driver window: Ti w }\end{array}$ \\
\hline ZE & $\begin{array}{l}\text { Vehicle outside: Thermocouples placed close to } \\
\text { the external surface of the fire-protection fabric } \\
\text { (fire exposure from Zone B) }\end{array}$ & $\begin{array}{l}\text { Motor zone: Te 1 } \\
\text { Boot zone: Te 2 } \\
\text { Driver door zone: Te 3 and Te 4 }\end{array}$ \\
\hline ZM & Intermediate zone: Thermocouples placed between & Motor zone: Tm 1 \\
\hline
\end{tabular}




\begin{tabular}{|l|l|l|}
\hline $\begin{array}{l}\text { the internal surface of the fire-protection fabric and } \\
\text { the external casing of the vehicle (fire exposure } \\
\text { from Zone } B \text { ) }\end{array}$ & $\begin{array}{l}\text { Rear door zone: } \operatorname{Tm} 2 \\
\text { Driver door zone: } \operatorname{Tm} 3\end{array}$ \\
\hline
\end{tabular}

Table 4. PS500 sensors specifications

\begin{tabular}{|l|l|l|l|}
\hline Gas & Range & Resolution & Sensor type \\
\hline $\mathrm{CO}_{2}$ & $0-5 \% \mathrm{v}$. & $0.05 \% \mathrm{v}$. & Non Dispersive Infrared (NDIR) \\
\hline $\mathrm{CO}$ & $0-1000 \mathrm{ppm}$ & $1 \mathrm{ppm}$ & Electrochemical \\
\hline
\end{tabular}

Table 5. Maximum temperature values recorded by the thermocouples located inside the vehicle.

\begin{tabular}{|c|c|c|}
\hline Thermocouple & $\begin{array}{c}\text { Time } \\
(\mathbf{m i n}: \mathbf{s})\end{array}$ & $\begin{array}{c}\text { Temperature } \\
\left({ }^{\mathbf{}} \mathbf{C}\right)\end{array}$ \\
\hline Ti 1 & $30: 26$ & 41.31 \\
\hline Ti 2 & $27: 04$ & 41.97 \\
\hline Ti 3 & $30: 34$ & 40.98 \\
\hline Ti 4 & $31: 30$ & 41.97 \\
\hline Ti 5 & $32: 48$ & 41.31 \\
\hline Ti 6 & $31: 25$ & 42.30 \\
\hline Ti 7 & $21: 32$ & 41.97 \\
\hline Ti w & $08: 55$ & 47.25 \\
\hline
\end{tabular}

